대구파티마병원 ${ }^{1}$ 내과, ${ }^{2}$ 병리과

강균은 ${ }^{1} \cdot$ 김현수 $^{1} \cdot$ 이재광 ${ }^{1} \cdot$ 김동현 $^{1} \cdot$ 정비나 $^{1} \cdot$ 장지훈 $^{1} \cdot$ 여상명 $^{1} \cdot$ 손경락 $^{2}$

\title{
Simultaneous Manifestation of Gangliocytic Paraganglioma and Hetero- topic Pancreas of Ampulla of Vater Treated by Endoscopic Resection
}

\author{
Gyoun-Eun Kang', Hyunsoo Kim', Jae Kwang Lee', Dong Hyun Kim', Bi-Na Jeong', Ji-Hun Jang', Sang-Myung Yeo', \\ Kyung-Rak Sohn ${ }^{2}$
}

Departments of Internal Medicine and ${ }^{2} P a t h o l o g y$, Daegu Fatima Hospital, Daegu, Korea

Gangliocytic paraganglioma is an uncommon tumor of digestive system that is usually found in the second portion of duodenum. It is generally considered benign tumor, although few reports of local recurrences and regional lymph node metastases have been made. Gangliocytic paraganglioma is characterized by its histologic pattern including ganglion cells, spindle cells and epithelioid cells. Heterotopic pancreas, also known as ectopic pancreas, is a pancreatic tissue appeared outside of its normal location lacking anatomic or vascular connection with the pancreas. In duodenum, it is a relatively unusual lesion that may be found incidentally during surgery or endoscopy. We present a case of 39-year-old woman with gangliocytic paraganglioma combined with heterotopic pancreas in the ampulla of Vater successfully treated by endoscopic resection.

Korean J Pancreas Biliary Tract 2016;21(4):232-238

Keywords: Gangliocytic paraganglioma, Heterotopic pancreas, Ampulla of vater

\author{
Received May. 6, 2016 \\ Revised Jun. 27, 2016 \\ Accepted Jul. 13, 2016
}

Corresponding author : Hyunsoo Kim

Department of Internal Medicine, Daegu Fatima Hospital, 99 Ayang-ro, Dong-gu, Daegu 41199, Korea Tel. +82-53-940-7222 Fax. +82-53-940-7458 E-mail; khsmhi@gmail.com

\section{서 론}

신경절세포 부신경절종(gangliocytic paraganglioma)은 흔 하지 않은 소화기계 종양으로 대부분 십이지장에서 발견되 며, 조직학적으로 부신경절종과 유사한 상피양세포, 방추형 세포 및 신경절세포를 확인하여 진단할 수 있다. ${ }^{1}$

이소성 췌장은 췌장 고유 조직과 해부학적으로 떨어져 다 른 부위에 위치하는 췌장 조직으로, ${ }^{2}$ 식도로부터 항문까지 전
위장관에서 발생할 수 있으며 ${ }^{3}$ 그 위치에 따라 다양한 증상이 발현될 수 있으나, 주로 증상이 없이 우연히 발견된다. ${ }^{2,3}$

국내에서는 십이지장, 특히 바터팽대부에 발생한 신경절 세포 부신경절종과 ${ }^{1,4}$ 십이지장의 이소성 췌장의 증례 ${ }^{5}$ 가 각 각 드물게 보고되었으나 아직까지 신경절세포 부신경절종 과 이소성 췌장이 동시 발현된 보고는 없었다. 국외에서는 $\mathrm{Lau}$ 등 $^{6}$ 이 십이지장에 발생한 신경절세포 부신경절종이 이 소성 췌장에서 유래하였다고 보고하였다. 저자들은 상복부 
불편감으로 발견된 바터팽대부의 점막하 종양에 대해 진단 및 치료를 위해 내시경적 절제술을 시행 후 신경절세포 부신 경절종과 이소성 췌장이 동시 발견된 증례를 경험하여 문헌 고찰과 함께 보고하는 바이다.

\section{증 례}

39세 여자가 한달 동안 지속된 상복부 불편감을 주소로 내 원하였다. 과거력 및 가족력상 특이 소견은 없었으며 입원하 여 시행한 초기 활력 징후상 혈압은 $120 / 68 \mathrm{mmHg}$, 심박수 68 회/분, 호흡수 20 회/분, 체온 $36.4^{\circ} \mathrm{C}$ 였다. 이학적 검진상 우상복부 압통을 호소하였으며 흥부 청진에서 호흡음, 심음 은 모두 정상이었다.

일반 혈액검사에서 백혈구 $6,000 / \mathrm{mm}^{3}$, 혈색소 $12.9 \mathrm{~g} / \mathrm{dL}$, 혈 소판 $232,000 / \mathrm{mm}^{3}$ 였고 혈청 생화학검사에서 총 단백 $6.9 \mathrm{~g} / \mathrm{dL}$, 알부민 $4.2 \mathrm{~g} / \mathrm{dL}$, 총 빌리루빈 $0.27 \mathrm{mg} / \mathrm{dL}$, 아스파라진산아미 노전이효소 $16 \mathrm{IU} / \mathrm{L}$, 알라닌아미노전이효소 $18 \mathrm{IU} / \mathrm{L}$, 알칼리 성인산분해효소 $65 \mathrm{IU} / \mathrm{L}$, 감마글루타밀전이효소 $29 \mathrm{IU} / \mathrm{L}$, 아밀라아제 $46 \mathrm{IU} / \mathrm{L}$, 리파아제 $29 \mathrm{IU} / \mathrm{L}$, 혈액요소질소 $9.8 \mathrm{mg} /$ $\mathrm{dL}$, 크레아티닌 $0.6 \mathrm{mg} / \mathrm{dL}$ 로 정상이었다. 혈청 전해질검사 에서 나트륨 $140 \mathrm{mEq} / \mathrm{L}$, 칼륨 $4.2 \mathrm{mEq} / \mathrm{L}$, 염소 $104 \mathrm{mEq} / \mathrm{L}$, 인 $3.8 \mathrm{mg} / \mathrm{dL}$, 칼슘 $9.2 \mathrm{mg} / \mathrm{dL}$, 마그네슘 $1.9 \mathrm{mg} / \mathrm{dL}$ 로 정상 소견을 보였다.

복부 전산화단층촬영에서 바터팽대부 근처에 위치한 약 $1.4 \mathrm{~cm}$ 정도의 비교적 윤곽이 분명한 조영증강이 잘 되는 계
란형의 종괴가 관찰되었으며(Fig. 1) 병변 주변의 이상 림프 절비대나 원격장기 전이소견은 관찰되지 않았다.

상부위장관 내시경검사에서 바터팽대부에 개구부를 포함 하고 돌출된 상피하 종양이 관찰되었으며, 내시경초음파검 사에서 점막하층에 약 $14 \mathrm{~mm}$ 정도의 비교적 균질한 저에코 의 점막하 종양으로 확인되었다(Fig. 2). 주변의 림프절비대 소견은 없었고 담관 및 췌관의 침범이 없었으며 병변은 십이 지장 벽의 고유근층은 침범하지 않아 내시경적 절제가 가능 할 것으로 판단하였다. 진단 및 치료를 위해서 측시경을 이 용하여 내시경적 절제술을 시행하였다(Fig. 3A). 병변은 충 분히 십이지장 내강 내로 돌출되어 있었고 점막하층 병변으 로 에피네프린 주입시 종양의 범위를 파악하기 어렵기 때문 에 에피네프린 주입 없이 바로 올가미를 이용하여 절제를 시 행하였다. 절제시 유두 개구부가 절제 부위에 포함되어 췌장 염을 예방하기 위해 내시경적역행성담췌관조영술을 시행하 고 췌관에 플라스틱스텐트를 삽입하였다.

절제된 조직의 육안적 소견을 살펴보았을 때 원형으로 회 색조를 띄고 다소 단단한 병변과 그 주변으로 약간 부드러운 분홍빛의 병변이 관찰되었다(Fig. $3 \mathrm{~B}$ ). 육안적 병리 소견상 종양의 크기는 $2 \times 1.5 \times 1.2 \mathrm{~cm}$ 였으며 절제된 검체의 병리 결과에서 병변은 십이지장 제 2 부 점막하층에 위치하였고 절 제부의 경계부 침범 및 혈관 침범은 관찰되지 않았다. 현미 경 소견을 보면 유사분열은 관찰되지 않았으며 헤마톡실린 및 에오신(hematoxylin and eosin, $\mathrm{H} \& \mathrm{E}$ ) 염색상 두 개의 각 기 다른 병변 소견이 관찰되었는데, 한 곳은 주로 췌장 샘꽈
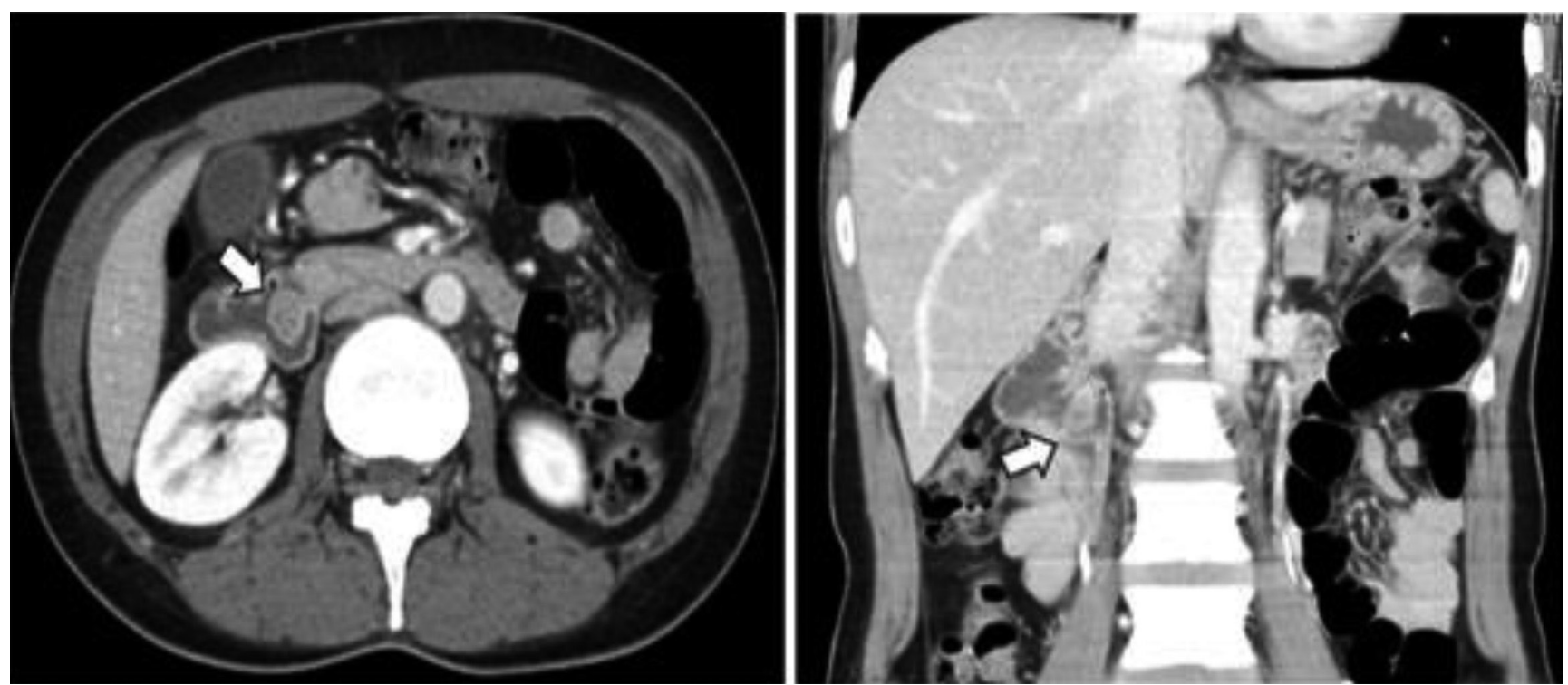

Fig. 1. Abdominal computer tomography showed a well enhancing mass, about a $14 \mathrm{~mm}$ sized (arrow), in the second portion of duodenum. 

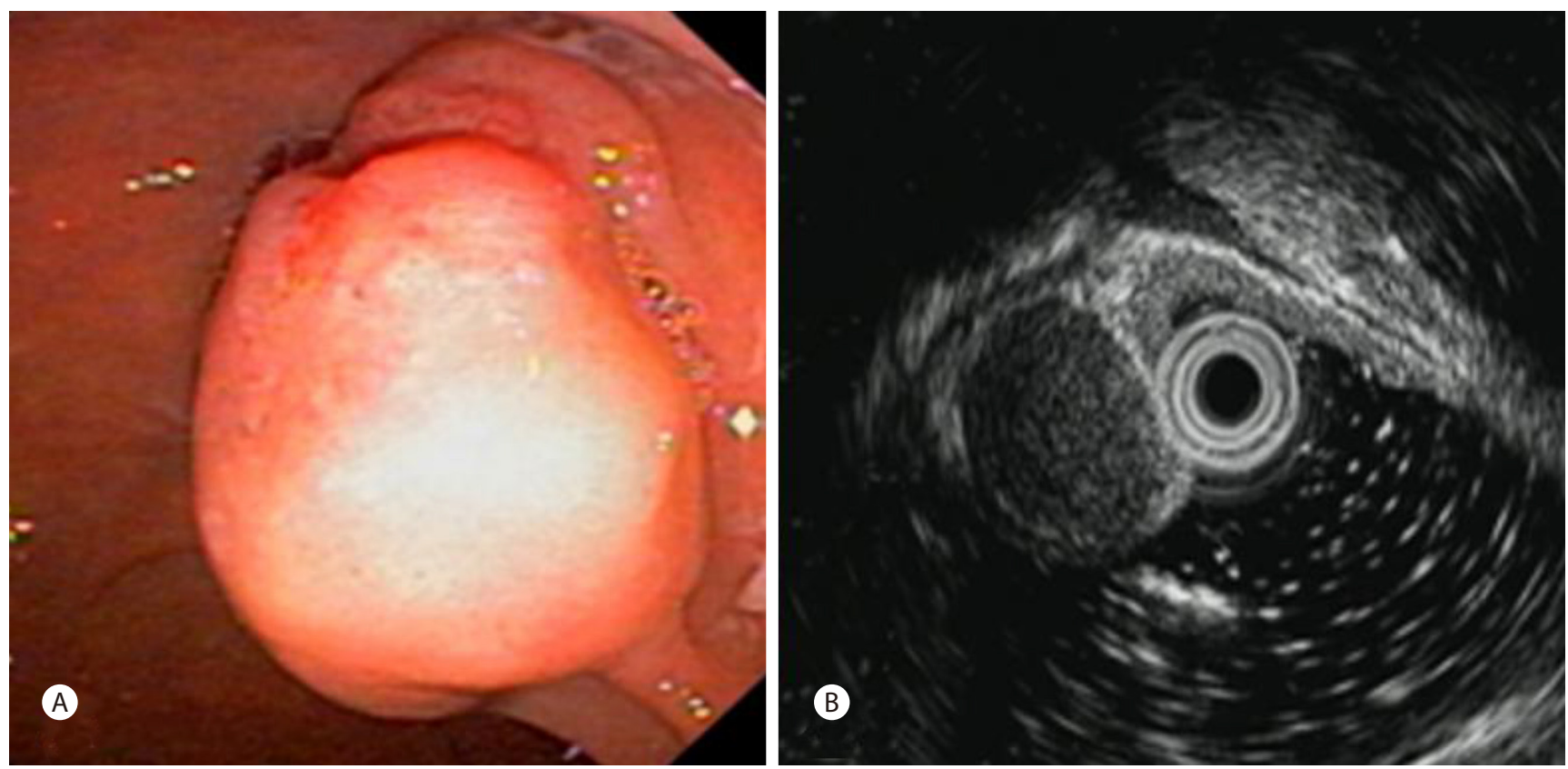

Fig. 2. (A) Duodenoscopy showed a polypoid submucosal tumor involving the papilla. (B) Endoscopic ultrasonography showed a homogenous hypoechoic mass.
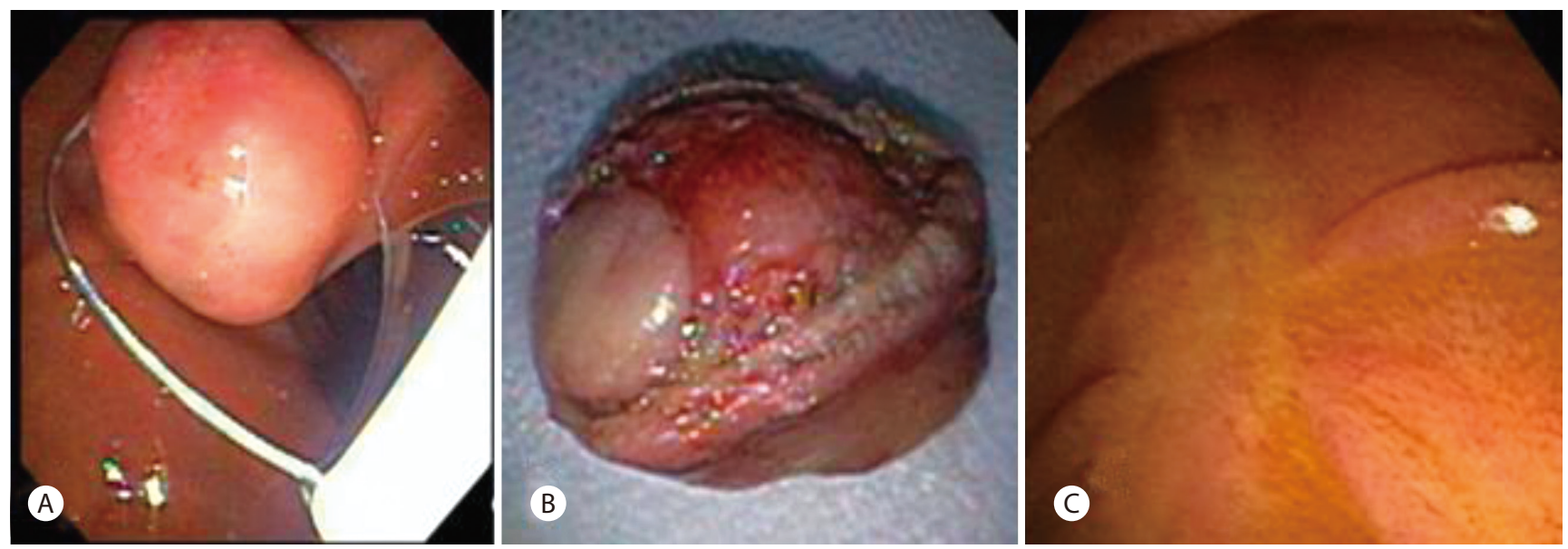

Fig. 3. (A) Endoscopic snare resection was done. (B) Gross findings of resected specimen showed well demarcated pale hard mass. (C) No recurrence of tumor was observed after 2 years of follow-up.

리 조직이 엽상 증식을 하는 췌장 조직을 관찰할 수 있어 이 소성 췌장으로 진단되었다(Fig. 4A). 그리고 주된 종양 조직 은 단조로운 상피세포성 군집이 둥글거나 죽상 모양의 배열 을 보이고 있으며 그 주변으로 풍부한 혈관 조직을 관찰할 수 있어 보편적인 부신경절종의 소견으로 판단하였다(Fig. $4 \mathrm{~B})$. 그리고 부분적으로는 신경절 모양이나 방추형 핵을 가 진 세포들이 통상적인 상피성 종양 조직과 섞여 있는 양상 또한 관찰할 수 있어 이는 신경절세포 부신경절종에 부합하 는 소견이었다(Fig. $4 \mathrm{C}, \mathrm{D}$ ). 최종적으로 면역조직학검사에서 chromogranin, CD56, synaptophysin 그리고 S-100 염색 양 성 소견을 보여 신경절세포 부신경절종으로 진단되었다 (Fig. 5). 이 두 병변은 서로 독립적으로 존재하였으며 이행부 위(transitional zone)는 없었다(Fig. 4A).

환자는 내시경적 절제술 후 양호한 경과를 보여 퇴원하였 으며 이후 약 2 년간의 지속된 추적관찰 상에 종양의 재발이 나 전이 소견은 관찰되지 않았다(Fig. $3 \mathrm{C}$ ). 

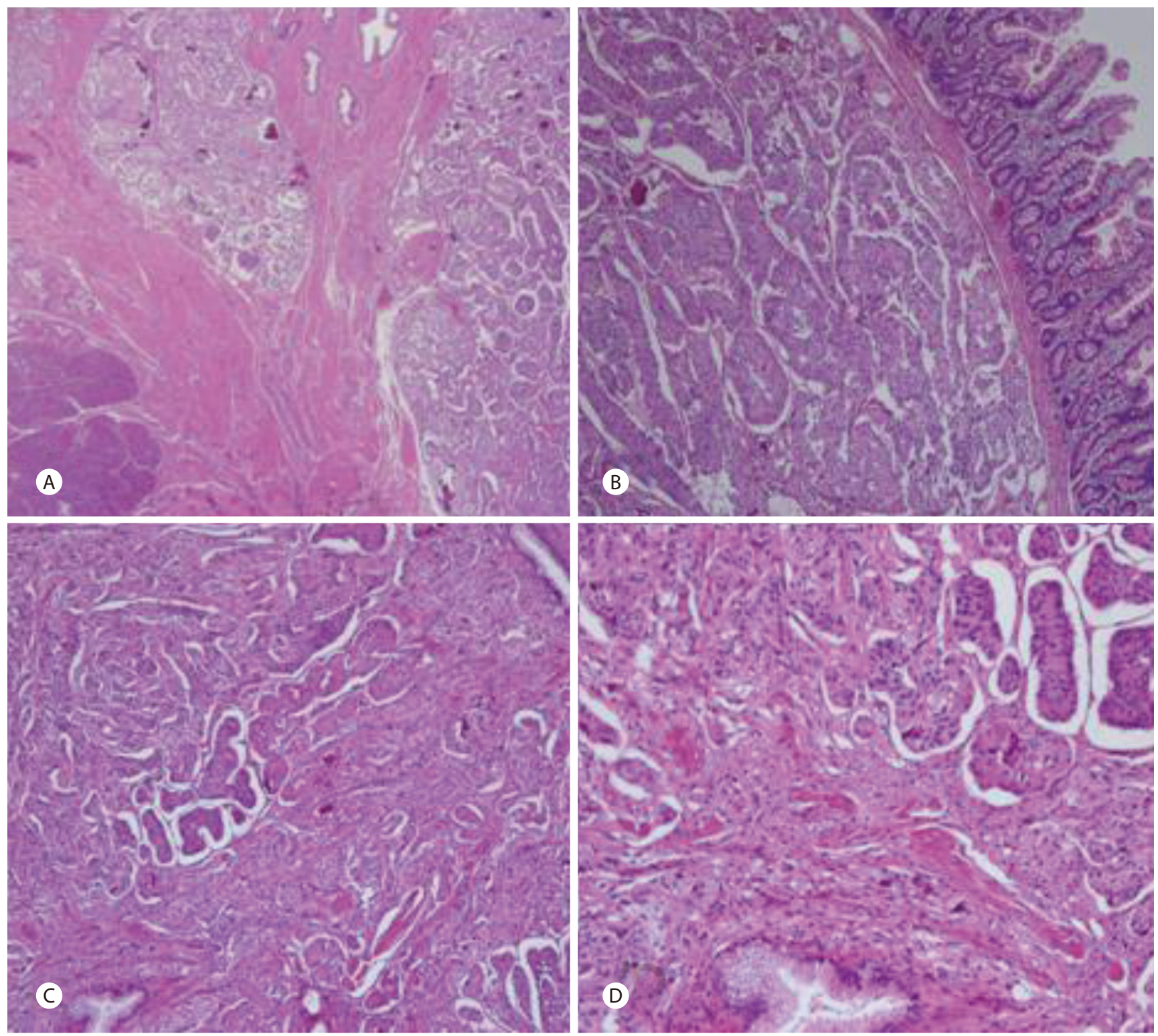

Fig. 4. H \& E stain. (A) Histological section shows two discrete lesions without transitional zone (left - ectopic pancreas and right - gangliocytic paraganglioma, $\times 20$ magnification). (B) Epithelial tumor cells express round nests or trabecular appearance with rich vascular stroma ( $\times 40$ magnification). (C, D) The tumor is composed of spindle cells, ganglion-like cells, and epithelial appearance (C: $\times 40$ magnification, D: $\times 100$ magnification).

\section{고 찰}

신경절세포 부신경절종은 드문 점막하 종양으로 부신경절 종과 유사한 상피양세포, 방추형세포 및 신경절세포의 구성 으로 이루어진 신경내분비 종양이다. 주로 십이지장의 제 2 부에서 발생하나 위 및 근위부 공장 등에서도 발생할 수 있 다. ${ }^{7}$ 남성이 여성보다 더 많으며(1.5-6:1 $)^{4}$ 발생 연령은 23세 에서 83 세까지 다양하나 주로 50 대에 발생빈도가 높다. 대부 분 무증상인 경우가 많으나 발생 위치에 따라 복통, 위장관
출혈, 폐쇄 등이 나타날 수 있다. ${ }^{7,8}$ 형태학적 소견으로 크기 는 $0.5 \mathrm{~cm}$ 에서 $10 \mathrm{~cm}$ 까지 다양하며 대부분 유경성 종괴의 양상을 보이며 점막하 단일 병변으로 발견된다. ${ }^{7}$

신경절세포 부신경절종은 조직학적으로 부신경절종과 유 사한 상피양세포, 방추형세포 및 신경절세포의 세가지 세포 로 구성되어 있으며, 그 성분 간의 구성 비율은 다양하다. $\mathrm{H}$ $\& \mathrm{E}$ 염색으로 위의 세가지 세포 성분을 확인하여 진단할 수 있으며 ${ }^{8}$ 면역조직화학 검사를 통해 각 세포의 성상을 구분할 수 있다. 일반적으로 면역조직화학 검사에서 방추형 세포는 

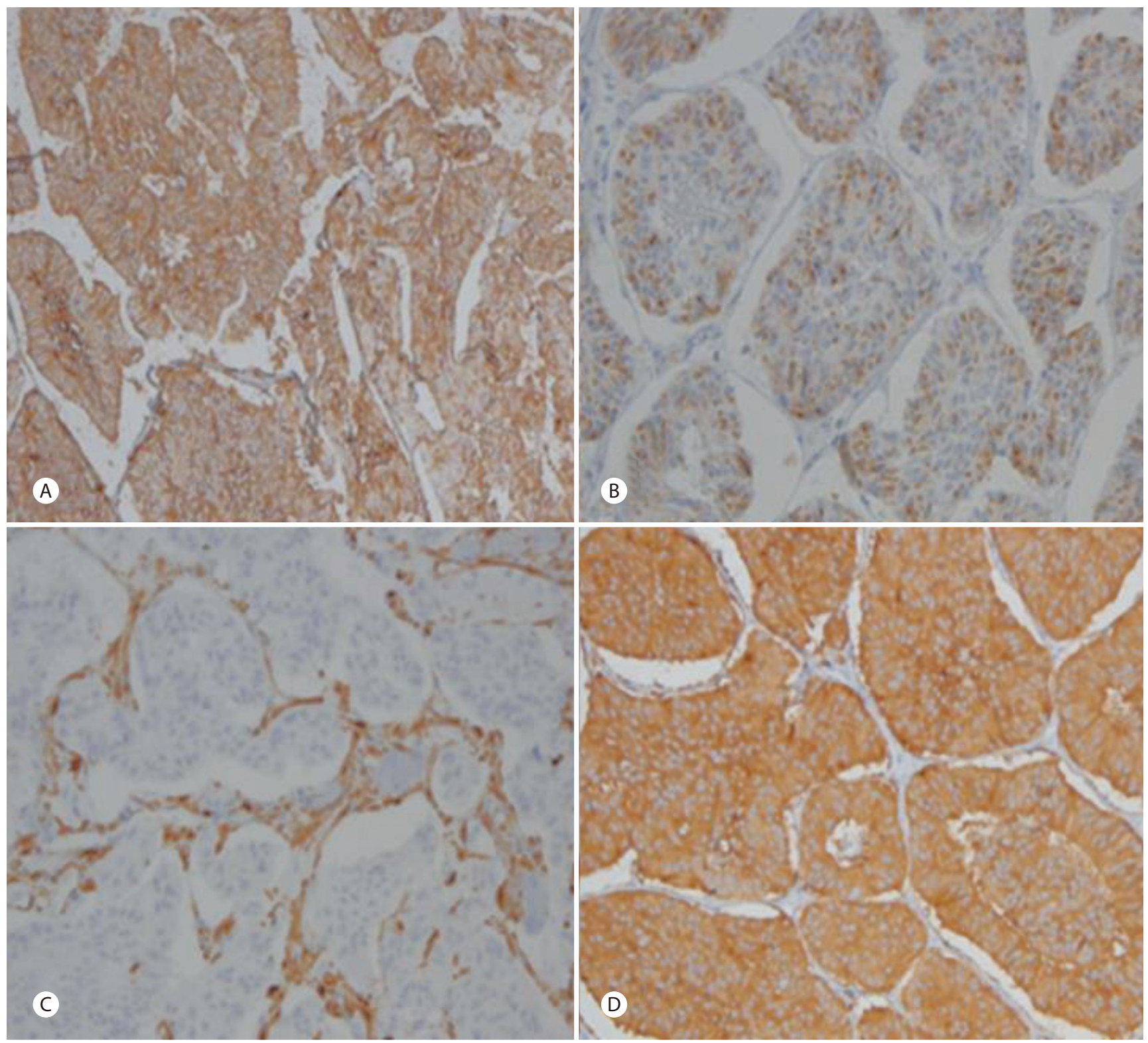

Fig. 5. Immunohistochemical stain. (A) The stain for CD 56 showed intense immunoreactivity in tumor cells ( $\times 40$ magnification). (B) Epithelioid cell nests expressed chromogranin ( $\times 100$ magnification). (C) The stain for S-100 protein revealed strong positive reaction in the surrounding sustentacular cells ( $\times 100$ magnification). (D) Epithelioid cell nests expressed synaptophysin (×100 magnification).

S-100, neurofilament protein 등에 양성 반응을 보이고 일부 에서는 CD56에 양성을 보인다. 신경절세포는 neuron-specific enolase, synaptophysin, somatostatin, CD56에 양성이 며, 상피양세포는 chromogranin, serotonin, somatostatin, $\mathrm{CD} 56$ 등에 양성 반응을 보이고 일부에서 neuron-specific enolase, cytokeratin 등에 양성 반응을 보인다. ${ }^{9,10}$ 본 증례의 경우 종양 조직이 세 가지 세포로 구성되어 있고 상기한 신 경내분비 표지에 양성 소견을 보이며 신경절세포 및 방추형 세포는 매우 국소적으로 관찰할 수 있는 증례이다.
이소성 췌장은 췌장 고유 조직과 해부학적으로 떨어져 다 른 부위에 위치하는 췌장 조직으로 ${ }^{2}$ 식도로부터 항문까지 전 위장관에서 발생할 수 있으며 그 위치에 따라 다양한 증상이 발현될 수 있으나, 증상이 없이 우연히 발견되는 경우가 대 부분이다. ${ }^{3}$ 이소성 췌장은 정상 췌장에서 나타날 수 있는 모 든 병적 변화가 발생하며 급성 및 만성 췌장염, 낭종, 농양, 출혈 및 괴사, 양성 및 악성 종양 등이 나타날 수 있다. 이소 성 췌장에서의 악성 변화는 고유 췌장 조직보다 더 많은 빈 도로 발생한다는 보고가 있으나 ${ }^{2}$ 임상적으로 이소성 췌장의 
악성 변화는 흔하지 않으며 약 $0.7 \%$ 에서 악성 변화를 관찰 하였다는 보고가 있었다. ${ }^{11}$ 한편 바터팽대부에 발생되는 이 소성 췌장은 매우 드물며 간혹 담관 폐쇄에 의한 황달 또는 복통을 일으킬 수 있다. ${ }^{12}$

십이지장의 신경절세포 부신경절종의 조직학적 발생 기원 은 아직 확실히 밝혀지지 않았으나 Perrone 등 $^{13}$ 은 췌장의 복 측 원기에서 유래한 상피세포의 과오종성 증식이라고 제안 하였고 이소성 췌장 조직에서 발생한 분리종 혹은 과오종이 라는 주장과 ${ }^{7}$ 배아 복강 신경절에서 발생한다는 가설, ${ }^{14}$ 창자 샘의 기저부에 있는 다능성 줄기세포에서 기원한다는 의견 등이 있다. ${ }^{15}$ 이 중 Burke와 Helwig 은 51명의 신경절세포 부 신경절종 환자를 대상으로 연구를 시행하였는데, 51 명의 환 자 중 대다수에서 췌장형 관 조직이 발견되었으며 췌장 폴리 펩티드 염색이 양성으로 관찰되었다. 이로 인해 Burke와 $\mathrm{Helwig}^{7}$ 은 신경절세포 부신경절종이 이소성 췌장 조직에서 발생한 분리종이라 주장하였다. 본 증례에서도 절제된 조직 에서 췌장 조직과 신경절세포 부신경절종이 동시에 관찰되 어 Burke와 Helwig 의 주장과 일치하나 명확한 이행부위가 관찰되지 않아 이소성 췌장과 신경절세포 부신경절종의 연 관성에 대해서는 추후 더 많은 연구가 필요하겠다.

신경절세포 부신경절종은 대부분 임상적으로 양성 종양의 경과를 보이며 재발 및 국소 림프절전이는 드물어 수술 전에 정확한 진단을 하는 것이 중요하나, 실제로는 수술 전 정확 한 조직 진단을 하기가 어려워 췌십이지장절제술과 같은 과 도하게 광범위한 수술을 시행하는 경우가 많다. 따라서 점막 하 종양인 경우 내시경 초음파로 종양의 존재 층이 점막하층 에 있다는 것을 진단하고 국소 림프절전이 및 주변 조직으로 의 침윤이 없다면 종양을 내시경적으로 국소적인 절제를 시 행할 수 있으며 이로 인해 불필요한 수술 및 수술로 인한 합 병증을 피할 수 있을 것이다.

본 증례에서는 상부위장관 내시경 및 내시경초음파로 확 인된 바터팽대부 점막하 종양에 대해 진단 및 치료를 위해 내시경적 절제술을 성공적으로 시행하였고 절제된 종양 내 에 신경절세포 부신경절종과 이소성 췌장이 공존하는 것으 로 진단되었다. 이는 아직 국내에서 보고된 바가 없어 상기 두 병변이 공존하는 것의 발견에 의의가 있으며 그 연관성에 대해서는 추후 더 많은 연구가 필요할 것으로 생각된다.

\section{요 약}

저자들은 상복부 불편감으로 발견된 바터팽대부 점막하 종양의 진단과 치료를 위해 시행한 내시경적 절제술상 신경 절세포 부신경절종과 이소성 췌장이 동시 발현된 증례를 경 험하여 문헌고찰과 함께 보고하는 바이다.

국문 색인: 신경절세포 부신경절종, 이소성 췌장, 바터팽대부

\section{Conflicts of Interest}

The author has no conflicts to disclose.

\section{REFERENCES}

1. Yang HM, Park HW, Kim S, Cho CM, Jung MK. A gangliocytic paraganglioma of the ampulla of vater treated by endoscopic snare papillectomy. Korean J Pancreas Biliary Tract 2013;18:52-58.

2. De Castro Barbosa JJ, Dockerty MB, Waugh JM. Pancreatic heterotopia; review of the literature and report of 41 authenticated surgical cases, of which 25 were clinically significant. Surg Gynecol Obstet 1946:82:527-542.

3. Dolan RV, ReMine WH, Dockerty MB. The fate of heterotopic pancreatic tissue. A study of 212 cases. Arch Surg 1974;109:762-765.

4. Park SJ, Kim DH, Lim H, et al. Endoscopic resection as a possible radical treatment for duodenal gangliocytic paraganglioma: a report of four cases. Korean J Gastroenterol 2014;63:114-119.

5. Chung JP, Lee SI, Kim KW, et al. Duodenal ectopic pancreas complicated by chronic pancreatitis and pseudocyst formation--a case report. J Korean Med Sci 1994;9:351-356.

6. Lau N, Hari D, French S. SOX10 expression in a gangliocytic paraganglioma--a case report. Exp Mol Pathol 2015;98:99-101.

7. Burke AP, Helwig EB. Gangliocytic paraganglioma. Am J Clin Pathol 1989;92:1-9.

8. Sakhuja P, Malhotra V, Gondal R, Dutt N, Choudhary A. Periampullary gangliocytic paraganglioma. J Clin Gastroenterol 2001;33:154-156.

9. Scheithauer BW, Nora FE, LeChago J, et al. Duodenal gangliocytic paraganglioma. Clinicopathologic and immunocytochemical study of 11 cases. Am J Clin Pathol 1986:86:559-565.

10. Guarda LA, Ordonez NG, del Junco GW, Luna MA. Gangliocytic paraganglioma of the duodenum: an immunocytochemical study. Am J Gastroenterol 1983;78:794-798.

11. Guillou L, Nordback P, Gerber C, Schneider RP. Ductal adenocarcinoma arising in a heterotopic pancreas situated in a hiatal hernia. Arch Pathol Lab Med 1994;118:568-571.

12. Chou SJ, Chou YW, Jan HC, Chen VT, Chen TH. Ectopic pancreas in the ampulla of vater with obstructive jaundice. A case report and re- 
view of literature. Dig Surg 2006;23:262-264.

13. Perrone T, Sibley RK, Rosai J. Duodenal gangliocytic paraganglioma. An immunohistochemical and ultrastructural study and a hypothesis concerning its origin. Am J Surg Pathol 1985;9:31-41.

14. Taylor HB, Helwig EB. Benign nonchromaffin paragangliomas of the duodenum. Virchows Arch Path Anat Physiol Klin Med 1962;335:356366.

15. Reed RJ, Caroca PJ Jr, Harkin JC. Gangliocytic paraganglioma. Am J Surg Pathol 1977;1:207-216. 